\title{
IN PURSUIT OF JUSTICE: ALBERT GEYSER'S STORY AS TOLD BY THE MEDIA
}

\section{Wim Dreyer}

University of Pretoria

wim.dreyer@up.ac.za

\section{ABSTRACT}

This contribution was delivered as a paper at the 2015 Conference of the South African Society for Church History. It reflects on the life and contribution of Prof. DrA.S. (Albert) Geyser, with specific reference to his leading role in the struggle against apartheid. Geyser was very active in the 1960s, but soon forgotten and erased from public memory. In this contribution Geyser is described as a well-known public figure and theologian, a view based on a large number of newspapers articles from this period. The reader is also presented with some reasons why Geyser's legacy is either ignored (being a controversial figure) or forgotten. It could be regarded as a 'contested' or 'forgotten' memory.

Keywords: Albert Geyser; apartheid; struggle; public theologian; justice; NHKA; media

\section{UNISA $\cong$}

Studia Historiae Ecclesiasticae Volume 41 | Number 3 | 2015 pp. 184-197
DOI: http://dx.doi.org/10.17159/2412-4265/2015/396 Print ISSN 1017-0499 | Online 2412-4265 (C) 2015. Studia Historiae Ecclesiasticae 


\section{INTRODUCTION}

Albert Geyser is one of the South African theologians whose struggle against apartheid is rarely mentioned or remembered.

Recently, this started to change. On 3 November 2011 Prof. Casper Labuschagne, professor emeritus of the University of Groningen gave a memorial lecture in Leeuwarden (Netherlands), in which he discussed the role Albert Geyser, Beyers Naudé and other Afrikaner theologians (himself included) played in the struggle against apartheid. One quote from this lecture will suffice to highlight the important role Geyser had played:

In de oecumenische studiegroepen bestond al lang de behoefte aan een instituut om onze activiteiten te coördineren en een tijdschrift om onze idealen van de eenheid van de kerk en een vreedzame samenleving uit te dragen. Daartoe is als eerste stap op initiatief van prof. Albert Geyser en dr. Ben Engelbrecht het christelijke maandblad Pro Veritate in het leven geroepen. Op voorstel van Geyser werd ds. Beyers Naudé uitgenodigd om het redacteurschap op zich te nemen. Hij ging akkoord en het eerste nummer verscheen in Mei 1962. (Labuschagne 2011, 13)

On 17 February 2014 the first annual Albert Geyser Memorial Lecture was presented at the University of Pretoria by Prof. J.A. Loader, dean and professor emeritus of the University of Vienna. It was published in HTS Theological Studies (Loader 2014). In another contribution in the same journal we read the following tribute to Geyser:

Unlike many of his compatriots, known for their iconic role in the struggle against apartheid, the name of Albert Geyser (10 Feb. 1918-13 June 1985) has faded from the collective memory of the public, ecclesiastical and theological discourse in South Africa and abroad. Other than with a political leader like Mandela and church leaders such as Desmond Tutu and Beyers Naudé, Geyser is not often, if at all, remembered in church and public life as one of the icons in the struggle against apartheid...A fitting and overdue gesture was made when the first memorial lecture in honour of Prof. Geyser was held on 17 February 2014 by the Faculty of Theology at the University of Pretoria. This memorial lecture highlighted the intellectual legacy and theology of Geyser that sought greater unity, compassion and reconciliation among groups and peoples, that rejected attempts to separate people because of their race. He needs to be remembered for more than his activism. Apart from being one of the giant figures in the struggle against apartheid, he was an esteemed New Testament scholar. (Van Aarde, De Villiers and Buitendag 2014)

As recently as 2015, from a most unexpected source, the legacy of Geyser was recalled. In the University of Cape Town (UCT) Legacy Society Newsletter Peter Silverman recounts:

The second lecture again at Jameson was by a person of incredible courage, Albert Geyser, a man whose Afrikaner credentials were by any definition impeccable, but opposed to Apartheid, a stance which cost him dearly. His own community disowned him, he was cast 
out as a traitor, and his personal safety questioned. I never got to meet him personally but I admired his courage. He ended his speech with words I have never forgotten: "It is not that South Africa has taken a moral step backwards. It is that the world has taken a moral step forward regarding the policy of Apartheid". (Silverman 2015, 17)

In the Christian Institute archives there is much evidence of the role Geyser played in the struggle against apartheid as chairman and driving force behind the Christian Institute. Published material normally attends more to the life and contribution of Beyers Naudé. Whereas Naudé had streets, academic centres and schools named after him (Labuschagne 2011), Geyser drifted away into oblivion, especially in the Afrikaner community. Some students of yesteryear are still able to tell anecdotes about Geyser or would recall with some admiration his outspoken criticism of church, government and society. However, as a public figure, Geyser disappeared.

The disappearance of Geyser in public memory is probably due to the fact that he became less involved in the struggle against apartheid because of personal circumstances. A positive assessment of Geyser's role in theology, church and society appeared in three scholarly contributions (Van Aarde 1992; Van Aarde et al 2014; Van Eck 1995). Details of Geyser's life and his theology can be found in these contributions. It is repeated here in a few sentences, just to establish some context. This contribution, however, attempts to tell the story as it unfolded in the newspapers of the time. The irony of it all is that Geyser, due to extensive media coverage, became one of the most famous academics in South Africa, a public theologian par excellence, invited to lecture to capacity crowds of students on various campuses only to fade away in public memory.

The sources used in this contribution are three volumes of newspaper clippings collected by Prof. Casper Labuschagne, co-activist, colleague and friend of Albert Geyser. The collection starts in 1960 and ends in 1968. Prof. Labuschagne entrusted his collection to me in 2014 when I visited him in Groningen. On my return I deposited copies of these volumes (totalling 400 pages and approximately 900 newspaper articles) in the archives of the Dutch Reformed Church (DRC) as well as the Ned. Hervormde Kerk van Afrika (NHKA). ${ }^{1}$

Because of the large volume of newspaper articles available as well as the fact that Geyser's pursuit of justice and struggle against apartheid can be divided in two clear periods (1955-1962 and 1963-1968), this is the first of two articles. In this article I will discuss Geyser's contribution between 1955 and 1963, as told by the newspapers of the time.

1 The unpublished volumes of newspaper clippings will be referenced (in example) as 'Labuschagne 2014 Vol. I:' with page number and if known, the original author. In most instances the author is indicated only as 'Staff Reporter'. 


\section{WHO WAS PROF. A.S. GEYSER?}

Albertus Stephanus (Albert) Geyser was born on 10 February 1918 on a farm close to Naboomspruit (Mookgophong), the heartland of Afrikaner conservative politics and a typical farming community. His father and mother (Petrus and Nina Geyser) were devout members of the Nederduitsch Hervormde Kerk van Afrika (NHKA). He was one of three children.

After he matriculated in 1935, Geyser and his brother (Hendrik Johannes) started their theological studies at the University of Pretoria. In 1938 Geyser completed his BA cum laude majoring in Greek and Latin. At the end of 1940 he completed his BD, also cum laude. He continued his studies and completed a MA (Classical Languages) in 1942 (Oberholzer 2010, 45). He had a sound knowledge of Hebrew, Syriac, Aramaic, Greek, Latin, French, German, Dutch and English. Including Afrikaans, he could read 10 languages.

In 1941 Geyser was ordained as minister in the NHKA Heilbron, a small town in the Free State. In 1944 he was called to a congregation in Pretoria where he served until 1946. At various periods he took leave to assist a congregation in Cape Town.

Geyser started with doctoral studies in Church History. He changed his doctoral studies to New Testament during 1944, primarily to be able to fill the position of Prof. J.H.J.A. Greyvenstein who retired in that time (Oberholzer 2010, 44-45). Within a year Geyser finished the doctoral exams and on 15 March 1946 he received the degree Doctor Divinitatis Cum Laude. His external examiner was Prof. J. De Zwaan of the University of Leiden. His thesis was titled Die geslagsregister van Jesus Christus volgens Matteus 1:1-17 en Lukas 3:23-38.

At the beginning of 1946, at the young age of 27, Geyser was appointed as lecturer in the Department of New Testament Studies at the University of Pretoria. Later that same year, he was promoted to full professor and Head of the Department. He served in this position until 1961, a period of 15 years. After he had accepted a position as professor of Theology at the University of the Witwatersrand in 1963, he first resigned as a minister of the NHKA and later (1968) as a member of the NHKA.

From the research which Geyser had published, his ability as theologian becomes quite apparent. In 1951, during the $175^{\text {th }}$ meeting of the Utrecht Theological Society, he was elected as one of five international members on the committee. In the same period he was invited to lecture at the University of Utrecht for a period of six months. At a later period (1959) he also participated in research at the University of Paris and the Vatican. During these periods of study he had contact with well-known scholars like Unnink, Rengstorf, Aland, Vielhauer, Cullmann, Barth, Berkelbach van den Sprenkel and Stauffer (Van Aarde 1992, 159). He served on the editorial boards of Novum Testamentum as well as its Supplementa.

In Europe, Geyser engaged with the growing international ecumenical movement. After his return from Europe, he became more and more outspoken in his criticism of apartheid. In 1955 he and Prof. S.P. Engelbrecht, his colleague at the 
University of Pretoria and professor of Church History, were two of the 13 Afrikaans academics who published a protest against the extended powers of the Senate and the removal of Coloured voters from the common voters roll. The involvement of two theologians in this action sent shock waves through the Afrikaner establishment.

In the period leading up to 1960 Geyser became quite outspoken against the ecclesiology of the NHKA, criticising the concept of a nationalistic church for Afrikaners as articulated in Article III of the NHKA church order (Van Eck 1995, 829). This was not only a question of political opposition to apartheid, but based on his fundamental understanding of the church as one, universal and holy church (Geyser 1960, 14-18; Van Aarde 1992, 160). He also engaged in debate with theologians from other churches, especially the Dutch Reformed Church, criticising their theological justification of apartheid (see Van Eck 1995 for an overview and theological analysis of the discourse).

During 1960, Geyser's opposition to apartheid became radicalised and outspoken, especially in light of the Sharpeville massacres and upcoming Cottesloe Consultation. During 1960 Geyser and 10 other theologians published a booklet with the title Vertraagde Aksie (Delayed Action). In this compilation of theological essays, direct or indirect criticism was directed against government and church policies. The 11 authors who contributed to the publication were from the NHKA, A.S. Geyser, A. van Selms, M.J. Redelinghuys and J. Stutterheim; from the DRC, B.B. Keet, B.J. Marais, G.C. Oosthuizen, J.A. van Wyk and G.J. Swart; from the Reformed Churches (GKSA) H. du Plessis and C. Hattingh.

What is remarkable in Geyser's introduction to his article in Vertraagde Aksie is the definitive influence of Karl Barth, although he does not mention Barth expressis verbis (Geyser 1960, 12-14). I am of the opinion that Geyser articulated Barth's views in a new context. There are clear similarities between Geyser's views and those expressed by Barth in a public lecture which he delivered on 22 July 1933, just before the important church elections in Bonn which determined the direction of the German church at the time of Hitler's assumption of political power in Germany. Barth pleaded with those present not to jeopardise the freedom of the gospel by voting for a direction which would enslave the church to nationalistic ideals (Barth $1933,7)$. He points out that neither nature, history nor culture:

...macht die Kirche zur Kirche und nicht von daher ist die Kirche als Kiche zu verstehen. Evangelium heist ja nicht: der Mensch für Gott!, sondern ganz und gar und allein: Gott für den Menschen. Will die Kirche Kirche sein und bleiben, dann muss sie zäh und eifersüchtig über dieser Verkündigung wachen als über ihrem Wesen. (Barth 1933, 6-7)

If 'the church wants to be church' it has to protect the freedom of the gospel which proclaims Jesus Christ as the only head and king of the church. In his contribution to Vertraagde Aksie Geyser echoes Barth's words: The challenge to the church is to be church! 
The Barthian influence on Geyser's ecclesiology and opposition to a nationalistic theology and apartheid in church and state also became evident during a debate in the 1961 General Assembly. During the debate which took five days to complete, Geyser mentioned that he showed the documents pertaining to racial segregation in church and state to Oscar Cullman and Karl Barth while on visit in Europe (NHKA 1961, 28 ). Both rejected it outright. The influence of Barth, more specific the struggle of the Bekennende Kirche against Hitler and the German Christian Movement as well as the Barmen Declaration were also addressed by Ben Marais in several newspaper articles of the time (Labuschagne 2014 Vol. I: 65).

Towards the end of 1960, while preparations for the Cottesloe Consultation of the World Council of Churches were in full swing, Geyser and Van Selms, an internationally acclaimed Old Testament scholar and Geyser's colleague at the University of Pretoria together with other ministers of the NHKA (see Geyser and Van Selms 1960a), prepared a Memorandum in which they criticised the policy of apartheid on theological grounds and rejected any form of biblical justification of apartheid (Geyser and Van Selms 1960b). They presented the Memorandum as ordained ministers of the NHKA to the Moderature on 28 November 1960 with the request that it would form part of the documentation to the Cottesloe Consultation (NHKA 1960, 28). It was rejected by the Moderature, although it contains some of the most lucid, well-constructed and theologically sound arguments against the policy of apartheid ever written in Afrikaans.

Geyser's pursuit of justice, opposition to apartheid, rejection of ecclesial exclusivity, exposure of racism in church and state as well as his critical theology provoked hostile reaction from political and ecclesial leadership, as well as fellow theologians at the University of Pretoria. After the 1961 General Assembly, Geyser had become isolated and persona non grata in many circles. It is at this point that we pick up the narrative as told by the media of the period.

\section{THE STORY OF GEYSER AS TOLD BY THE MEDIA, 1960-1963}

In this section a small selection of articles will be discussed in which we find some indication of Geyser's views as well as how he was viewed by the public and the media. It is quite impossible to give a complete overview of all the articles in the Labuschagne collection.

\section{Justice versus law}

On 22 April 1960, in the wake of the Sharpeville massacre (21 March 1960), Geyser published an article in Weekblad (Labuschagne 2014 Vol. I: 1) in which he argues that a plethora of laws had replaced justice in South Africa. In quite a long, full-page 
article he gives an overview of 12 years of legislation which gave the government dictatorial powers. He makes the point that the more a government needs laws to govern, the less it is based on justice and conscience. He equates the massive growth in legislation to the situation in Italy and Germany under Fascism and in Russia under Communism. He comes to the conclusion that the violent protest action at Sharpeville was the result of laws which disenfranchised a large section of the population who had no other possible way to voice their opposition to a government which had lost the ability to listen to people.

On 11 May 1962, after Geyser had been found guilty of heresy by the church and removed from office, Geyser told a Rand Daily Mail reporter that 'South Africa would be overtaken by a terrible calamity unless human relations were motivated by true Christian values and principles'. Geyser expressed the opinion that a peaceful and orderly life in South Africa could only be found in a common conscience with a common content of moral values, in a society based on justice and respect for human dignity.

\section{Anti-apartheid activism}

Hendrik Vorster reported (Sunday Times, 20 November 1960) that '350 ministers' of the various Afrikaans churches had been meeting regularly and in secret during 1960 , to discuss the government's policy of apartheid, the infringement of the basic rights of human beings and the effects it could have on the church (Labuschagne 2014 Vol. I: 6). There were even signs of 'revolt' against ecclesial leadership. In the article Geyser, as one of the leaders of the movement, is quoted as saying:

\footnotetext{
Many of the aspects of apartheid as they affect the church have caused deep anxiety among churchmen in South Africa. We have studied them intensively at our various meetings over the past six months in Johannesburg and Pretoria. Now individual theologians have, for the first time, expressed their anxieties and have analysed the problems facing the church as we see them.
}

Vorster explains that the publication Vertraagde Aksie (which has been referred to above) was the culmination of six months of study and secret meetings and must be understood as a public protest of theologians against racial segregation in church and state. He quotes reverend M.J. Redelinghuys of the NHKA, who described the theology supporting apartheid as an attempt to nationalise God and to reduce Him to a tribal god. Redelinghuys described South Africa as becoming a 'police state'.

The very next day (21 November 1960) Geyser published a repudiation of the article in Sunday Times in the Afrikaans newspaper Transvaler (Vol. I, 7). He denied that the meetings were ever 'secret', that they were planning a 'revolt' against church leadership and mentioned that the organisation/study group which they belonged to was called the Ekumeniese Studiekring which had 108 members and was open to anybody. Dr G.J Swart, secretary of the Studiekring, confirmed this. In the next 
issue of the Transvaler (22 November 1960), the editor took it upon himself to warn Afrikaans theologians not to trust the 'English press', as they will misuse the opportunity to score political points.

Early in January 1961 a massive meeting of ministers and church members took place in Brits, just north of Pretoria. In an article in Die Burger (7 January 1961), a report is given of prominent church leaders and theologians who rejected the views expressed in Vertraagde Aksie (Labuschagne 2014 Vol. I: 8). Some of the prominent figures were prof. A.D. Pont (NHKA) and prof. A.B. du Preez (DRC). Under loud and enthusiastic applause Pont delivered a scathing attack on the authors of Vertraagde Aksie. The meeting concluded (as reported) that 'if the Afrikaner nation would disappear from South Africa, Christ Himself would disappear'. Pont argued that the authors of Vertraagde Aksie are promoting the suicide of the Afrikaner nation.

\section{Afrikaner Broederbond}

Another theme which appeared frequently in newspapers of the time, is the role which the Afrikaner Broederbond played in the churches. The Sunday Times (22 May 1960) reported that there was a growing resentment amongst influential Afrikaners against the tight grip the Broederbond had on politics, economics, religion and even the SABC (Labuschagne 2014 Vol. I: 2, 3). Geyser was outspoken in his criticism of the Broederbond and at one stage leaked secret documents to the press in which several prominent leaders of the Afrikaans churches were named as members of the secret society. The Broederbond was described as a cancer in the bosom of the church. It was pointed out as untenable that a secret society should influence ecclesial decisions, rather than Scripture alone.

Geyser's father was also a member of the Afrikaner Broederbond. In the wake of Geyser's public criticism of apartheid and the role of the Broederbond in the church, Geyser senior was asked to resign from the organisation, which he did. Geyser's father, mother and wife supported him throughout, but his brother (also a minister in the church) rejected his views and basically disowned him.

\section{Charge of heresy}

Benjamin Pogrund broke the news on 5 October 1961 in the Rand Daily Mail that a charge of heresy had been laid against Geyser (Labuschagne 2014 Vol. I: 10). The charges were laid by three senior theological students. Geyser was asked by the Moderature to resign his position as lecturer in New Testament, but he refused due to the fact that the charge of heresy was without 'any basis of fact'. On the same day, Geyser told a reporter of the Pretoria News (Vol. I, 11) that he was deeply shocked by the fact that his own students laid a charge of heresy against him. He denied that he was a heretic and made it clear that he wanted to defend himself on the charges and would ask that the proceedings would be open to the public and the press. 
In London, the Daily Mail (12 October 1961 Vol. I: 13-14) published an article based on telephonic interviews it had had with four well-known Dutch theologians: Prof. P.A. Stampvoort (Groningen), Hendrikus Berkhof (Leiden), J.N. Bakhuizen van den Brink (Leiden) and B. Gemser (emeritus of the University of Pretoria living in Groningen). They were unanimous in their condemnation of the heresy charge, calling Geyser one 'of the most brilliant theologians of South Africa' whose credentials and credibility was impeccable. They were unanimous in their view that the charge of heresy against Geyser was politically motivated, orchestrated by the Afrikaner Broederbond and devoid of all theological substance. Two days later the Mail also carried a report on Rabbi B. Isaacson who called Geyser a 'Noah of this generation' during a sermon he delivered in the Krugersdorp Synagogue. He found Geyser's actions 'inspiring and refreshing', a man who did not sacrifice his principles on the altar of expediency.

The heresy charge against Geyser coincided with a vote in the United Nations which censured South Africa (Vol. I, 15). The Sunday Times reported (15 October 1961) that a major crisis was looming in relations between the Netherlands and South Africa, under the heading 'Grave crisis in S.A. Holland relations'. According to the Sunday Times reporter, the 'grave crisis' was precipitated by two factors, namely the Netherlands who had been the only European country to vote with the Afro-Asia block in the United Nations to censure South Africa, and secondly the severe and public condemnation by the Nederlands Hervormde Kerk of the charge of heresy against Geyser. The general feeling expressed by Prof. Hendrikus Berkhof was that normal relations with the NHKA had become impossible. In the same statement the Dutch church expressed its support for the decisions of the United Nations. The Geyser trial again surfaced at the United Nations on 8 November, when the South African minster of Foreign Affairs, Mr Eric Louw, was called to address the UN Commission on the issue (Transvaler, 9 November 1961 Vol. I: 48).

The heresy trial started on 24 October 1961 under massive public interest. At least 25 national and international newspapers had reporters on standby at the church offices, but they were denied access to the trial. The area around the offices was packed with interested members of the public, who were also denied entry except if they were members of the NHKA. So many members of the church attended the trial that they had to sit on the floor in a hall which could seat 450 people (Vaderland, 25 October 1961 Vol. I: 26). On the day the trial started, the Utrecht Theological Faculty sent an official telegram to the Pretoria Faculty of Theology to do their utmost to stop the trial (The Star, 24 October 1961 Vol. I: 19). It was followed by a telegram from the Praeses of the Dutch General Synod delivered to the Moderature of the NHKA, imploring them not to take any decisions which would jeopardise the Reformed principles of the church. Telegrams of support were sent to the Geyser home, including from several theological faculties such as Groningen and Pittsburgh Theological Seminary, which invited Geyser to apply for a position (Vol. I, 50). 
Newspapers carried reports on a daily basis in which the trial's progress was described. Personal profiles of Geyser, Mrs Celia Geyser (who confirmed her support of her husband's views), his father, the accusers (H.G. van der Westhuizen, E. Engelbrecht and W.C.M. de Beer) as well as the members of the Moderature were published. Geyser was depicted as a staunch Hervormer with an Afrikaner lineage going back two centuries. The Rand Daily Mail (24 October 1961) writes:

Born and brought up in the fervent tradition of Afrikaner nationalism, the descendent of an early Trekker family, a brilliant and highly-regarded theologian in a conservative church, now a self-admitted crusader against the intolerances and abuses of nationalism...(Vol. I, 18).

It continues to describe how deeply Geyser had been influenced by books he read on the struggle of Christianity against Nazism in Germany and his growing conviction that Christianity, nationalism and authoritarianism could never be reconciled.

Geyser was charged with heresy and insubordination. The insubordination charge was based on his public rejection of decisions taken by the General Assembly regarding segregation in church and state. The heresy charge was based on lecture notes which students had taken down, especially his lectures on the Letter to the Philippians and his exposition of Christ's relationship to God the Father in light of Chapter 2:6-11. According to the students who laid the charges, Geyser taught the subordination of the Son to the Father. This was widely regarded as a smoke screen for the real issue, namely his opposition to apartheid.

After three weeks of trial, with some stoppages due to Geyser's deteriorating health, newspapers started reporting on open revolt amongst church members against the prolonged trial. Individual members who resigned from the church were interviewed: 'Oom Danie, 73, is looking for another church' (Sunday Times Vol. I: 50). The article tells the story of a farmer (Danie Naudé) from Naboomspruit who was a founder member of the National Party in the Waterberg, who realised 'God never said serve me by the laws of the church. He called on all men to serve Him together...'. Some members openly discussed and mentioned a split in the church (Pretoria News, 16 November 1961 Vol. I: 51) and many simply left the church or transferred their membership to other denominations.

When the first part of the hearings concluded on 16 November 1961, a large part of the recordings of the trial was already transcribed and 409 typed pages were handed to Geyser to prepare his defence (Vol. I, 53). The trial continued until 5 December, took a break for the holidays and resumed again on 30 January 1962. It continued intermittently until April. By that time the typed proceedings covered 3 000 pages. In the meantime Geyser was removed from his position as Bible translator and rumours surfaced that he was offered a position as professor at the University of the Witwatersrand. On 8 May 1962 Geyser was informed that he was found guilty 
of heresy, not guilty on the charge of insubordination, and deposed as minister of the church (Rand Daily Mail, 9 May 1962 Vol. I: 56). The trial eventually lasted six months, in which the 15 members of the Commission had to attend all sessions taking leave from their regular occupation. The final proceedings cover 4000 pages and the financial costs, if calculated in today's terms, ran into millions.

The Transvaler (9 May 1962) published the verdict in toto (Vol. I, 57). In the verdict it was spelled out that Geyser was reckless in the way he confronted the students in class with different interpretations of Scripture, some contrary to the confessions, to such an extent that students' faith was undermined. Interestingly enough, Geyser did not resign as member from the NHKA, even though he was removed from office. The Rand Daily Mail (10 May 1962) summed up the events in a main editorial under the heading 'Heretic or rebel?'

The "trial" of Dr Albert Geyser, Professor of New Testament Theology at the University of Pretoria and minister of the Nederduitsch Hervormde Kerk, on charges of heresy and insubordination has been one of the most extraordinary events of recent years in South Africa and the outcome has been equally remarkable...if he had been a political conformist, his theological views would never have been questioned...Dr Geyser has been pilloried for his moral stand on race questions - whatever has been decided against him on theological grounds. (Vol. I, 62)

This was a general view expressed in publications, but vehemently denied by the church which insisted that the trial was about doctrine only.

\section{The conflict continues}

After the trial and Geyser's removal from office, he received more than a thousand letters of support from all over the world. He received several invitations to deliver speeches and to preach in various churches. The Pretoria News reported that Geyser, during a sermon (on the text of Hebrews 5:8) in the Congregational Church of Pretoria, told the congregation 'that a church which has no compassion with suffering, irrespective of race or creed, has lost its Christianity...' (Labuschagne 2014 Vol. II: 1). Christians needed to be brave in the face of threats and intimidation, probably referring to the fact that he received several death threats, abusive phone calls and letters condemning his views.

On 16 May 1962 the Rand Daily Mail reported that Prof. Adrianus van Selms resigned his position as professor of Old Testament at the University of Pretoria as a protest against the verdict against Geyser. In his letter of resignation he states: 'Conscience forbids me to allow any human being to dictate to me what the Divine Word says' (Vol. II, 2). The theme of justice, human dignity and conscience was also the main focus of a lecture which Geyser delivered to a packed hall of between 1600 and 2000 students on the campus of the Witwatersrand University (Pretoria News, 16 May 1962). Geyser pointed out that the lack of human dignity in South Africa 
was leading it to its destruction. South Africa, he said, was prepared to hang a man because he tries to protect human dignity. Without the concept of justice and human dignity there is no civilisation. South Africans have become 'mental acrobats', turning justice into self-righteousness, love into self-love and respect for life into self-preservation.

Following the conviction of Geyser and the resignation of Van Selms, other lecturers also came under fire. The Sunday Times reported (30 September 1962) that Dr Casper Labuschagne, a 'new deal' theologian, had been dismissed as lecturer in Biblical Studies at the University of Pretoria because, it was believed, he was an ally of Geyser and a critic of apartheid. Labuschagne challenged the decision but was informed that it was a 'practical' arrangement due to the change in the structure of the theological curriculum (Dagbreek, 14 October 1962 Vol. II: 7). Labuschagne relocated to Groningen where he was appointed as lecturer and later professor of Old Testament. During this period Geyser also received an appointment at the University of the Witwatersrand in the Department of Divinity. However, he remained a member of the NHKA.

Geyser appealed his conviction in the Supreme Court of South Africa. The case started on 1 May, 1963. Geyser asked the court, under presiding judge J.F. Ludorf, to set aside his conviction of heresy (Vaderland, 1 May 1963). Geyser's argument in court was that the findings of the heresy trial should be set aside because the members of the commission were biased, acted male fide and the process was fraught with irregularities. During the trial Geyser recited the Articles of Faith and confirmed that he had always believed in the church as the Trinity. On 14 May the hearing was postponed, to give the parties an opportunity to come to some agreement. On 15 May 1963 the trial ended dramatically, when the court heard that Geyser had been restored to his office as minister of the NHKA. The church undertook to pay all legal fees. The Commission of the General Assembly (Moderature) also declared publicly that it had made a 'bona fide and unintentional mistake' in the interpretation of Geyser's viewpoints. It is clear the church realised it would lose the court battle.

\section{CONCLUDING REMARKS}

This very short overview of events surrounding Geyser as told by various newspapers between 1960 and 1963, makes it clear that Albert Geyser was regarded by many as a leading figure in resisting the destruction of justice, human dignity and equality in South Africa. What made it remarkable was the fact that he came from a very conservative political and ecclesial background. His ability to transcend racial, cultural and religious boundaries made him a credible voice in the resistance against apartheid.

Geyser was by no means easy to get along with. He was highly intelligent, welleducated and well spoken. He used his ability as public speaker to arouse emotion. 
He could be scathing in debates and demolish opponents' arguments. He did not back away from confrontation. Many regarded him as arrogant. The negative or positive evaluation of Geyser depended mostly on the eye of the beholder - in the Afrikaans and church press he was often criticised, even maligned; in the English press he became a national hero of resistance and a true prophet. Internationally he was regarded highly as a man of integrity.

Geyser could be regarded as the most influential public theologian of the early sixties. This makes it even more remarkable that he was so quickly forgotten and erased from the collective memory. The skewed or even complete lack of knowledge of Geyser's life and work in the church which he loved and was buried from, is probably the result of church historians who underplayed or gave a specific interpretation of the events. Geyser was a controversial figure and his is a 'contested' memory. Because of the massive loss of credibility the church suffered during the whole Geyser debacle, he is rarely mentioned or discussed and very often presented in a negative light.

In a next contribution the story must continue, because Geyser soon became involved in a new wave of controversy when he and Beyers Naudé established the Christelike Instituut, attended meetings of the World Council of Churches and published Pro Veritate. He was branded a 'communist who will be responsible for the murder of Afrikaner women and children'. This also ended in court, which awarded him the biggest libel claim in the legal history of South Africa.

\section{REFERENCES}

Barth, K. 1933. 'Für die Freiheit des Evangeliums.' In Theologische Existenz Heute Heft 2, Chr. München: Kaizer Verlag.

Geyser, A.S. 1960. 'Die Eerste Evangelie oor die eenheid van die kerk as Christusgetuienis.' In Vertraagde aksie: 'n Ekumeniese getuienis vanuit die Afrikaanssprekende kerk, Geyser, A.S. and Keet, B.B. (Ed.) 1960. Pretoria: published by the editors.

Geyser, A.S. and Van Selms, A. 1960a. 'Brief aan Algemene Kommissie.' In Handelinge van die Kommissie van die Algemene Kerkvergadering Januarie 1960 tot Desember 1960, p. 28. Pretoria: NHKA Archives.

Geyser, A.S. and Van Selms, A. 1960b. 'Memorandum.' In Handelinge van die Kommissie van die Algemene Kerkvergadering Januarie 1960 tot Desember 1960, p. 28-40. Pretoria: NHKA Archives.

Labuschagne, C., 2011. Beyers Naudé en het verzet tegen apartheid. Achtergrond informatie van een medestrijder van het eerste uur. Unpublished lecture on the $90^{\text {th }}$ commemoration of the Christelijk Gymnasium Leeuwarden on the $5^{\text {th }}$ commemoration of its name change to the Beyers Naudé Christelijk Gymnasium.

Labuschagne, C. 2014. Geyser Newspaper Clippings (Vol. I, II \& III), Pretoria: NHKA Archives. 
Loader, J.A. 2014. 'Understanding of failure and failure of understanding: Aspects of failure in the Old Testament.' HTS Teologiese Studies/Theological Studies 70(1), Art. \#2657, 11 pages. http://dx.doi.org/10.4102/ hts.v70i1.2657

NHKA 1960. Handelinge van die Kommissie van die Algemene Kerkvergadering, p. 28-40. Pretoria: NHKA Archives.

Oberholzer, J.P. 2010. 'Honderd jaar kerk en teologiese opleiding: 'n kroniek van die Hervormde Kerk.' HTS Teologiese Studies/ Theological Studies, Supplementum 9 (Vol. 66/3).

Silverman, P. 2015. 'Those many years ago', UCT Legacy Society Newsletter 2015, p. 15-17, University of Cape Town.

Van Aarde, A.G. 1992. 'A.S. Geyser, teologiese dosent 1946-1961.' HTS Teologiese Studies 48/1 \& 2 (1992), p. 159-182.

Van Aarde, A.G., De Villiers, P.G.R. and Buitendag, J. 2014. 'The forgotten struggle of Albert Geyser against racism and apartheid.'HTS Theological Studies 70 (1), Art. \#2820, 10 pages http://dx.doi.org/10.4102/hts.v70i1.2820

Van Eck, E. 1995. 'J.H.J.A. Greyvenstein en A.S. Geyer se teologiese denke oor die volkskerkgedagte.' HTS Teologiese Studies 51/3 (1995), p. 825-850. 